\title{
CHARACTERIZATION OF ENDOPHYTIC BACTERIA ASSOCIATED WITH SOME MEDICINAL PLANTS
}

\author{
Eman A.S. Ahmed ${ }^{1 *}$, Enas A. Hassan², El-Tobgy ${ }^{1}$ K.M.K. \\ and Elshahat M.Ramadan ${ }^{2}$
}

1- Central Lab., Horticulture Research Institute, Agric. Res. Cent., P.O. Box 12619, Giza, Egypt.

2- Agric. Microbiology Dept., Fac. of Agric., Ain Shams Univ., P.O. Box 68, Hadayek Shubra 11241, Cairo, Egypt.

${ }^{*}$ Corresponding author: emadel21@yahoo.com

Received 3 October, 2019

Accepted November, 2019

\section{ABSTRACT}

A total of 89 endophytic bacterial cultures were isolated by two techniques from seven medicinal plants; Coriandrum sativum, Anethum graveolens, Pelargonium graveolens, Ocimum basilicum, Rosmarinus officinalis, Saliva officinalis and Origanum majorana. To address the biological activity of these isolates as endophytic bacteria, preliminary screening showed $44,36,28,22,82$ isolates out of total one gave positive results for cellulase, pectinase, amylase activities, indole acetic acid (IAA) and gibberellic acid $\left(\mathrm{GA}_{3}\right)$ production, respectively. The secondary screening twenty endophytic bacterial isolates were selected and examined for their antagonistic effect against four pathogenic fungi, antioxidants activity, total phenols, indole acetic acid, ammonia $\left(\mathrm{NH}_{3}\right)$, siderophores production and nitrogenase activity. According to the last screening; six isolates were chosen because of their multi-plant growth promoting (PGP) traits. They recorded a wide range of total flavonoids concentration in endophytic bacterial supernatant. The values of total flavonoids varied from 1.43 to 31.14 ppm. While the alkaloids production was detected by all tested isolates except isolate S14. Isolate B3 gave the maximum alkaloids concentration in its supernatant being $0.34 \mathrm{ppm}$. Four isolates are able to solubilize phosphate, low variations between tested isolates in phosphate solubilization ranged from $5.65 \mathrm{ppm}$ by isolate R014 to $3.85 \mathrm{ppm}$ by isolate $\mathrm{C} 8$. All isolates showed negative result for hydrogen cyanide $(\mathrm{HCN})$ production. Furthermore, the colonization of the six most efficient isolates inside the tissue of two medicinal plant Ocimum basilicum and Coriandrum sativum were performed by two techniques; 2,3,5-triphenyl tetrazolium chlo- ride (TTC) stain and Transmission electron microscope (TEM). Based on some morphological and biochemical characteristics of the most efficient isolates (RO10, RO14, S14, D6, C8 and B3); the six isolates were similar to three genera (Enterobacter sp., Aeromonas sp. and Bacillus sp.). Hypersensitivity test proved that all the six endophytic bacterial isolates are nonpathogenic bacteria. Where, these isolates gave negative symptoms of hypersensitivity reaction (HR) test on the pepper plants (Capsicum annuum) used as indicator plant.

Keywords: Endophytic bacteria, Medicinal plants, TEM, TTC Stain, Endophytic colonization, PGP.

\section{INTRODUCTION}

Recently, there is an increasing in consumption rate of fertilizers around the world, causes critical problems to environment. This excess using of chemical fertilizers can increase the accumulation of heavy metals in ground water, soil and plant body. Beside, Plants absorb this inorganic fertilizers from the soil which can enter the food chain then reached to human and animals. Thus, Agrochemical applications lead to soil, water and air pollution (Serpil, 2012). Great attention focuses to minimize the harmful effects of the classical application of agriculture, a new techniques based on microbial inoculation are now gaining more interest (Hassan, 2017).

The term of 'Endophytic' is a kind of microbes which resident in the intercellular or intracellular area of healthy plant tissues during their periods of life or the whole, without cause any visible symptoms or show harmful effects to plant hosts (Aly et al 2011). These microorganisms help their plants 
hosts by producing a number of bioactive metabolite which presented protection and enhance the growth of their hosts (Sánchez-López et al 2017). The host plant provides endophytic bacteria with a rich habitat while endophytic bacteria supply nutrients to plants like soluble potassium, iron, and phosphate, fixed nitrogen and produced phytohormones (Sánchez-López et al 2017). So, these endophytic microbes are a great tool in strategy for sustainable agriculture because they can minimize the environmental pollution from chemical application of fertilizers and other inorganic pesticides ( $\mathbf{L i}$ et al 2018). Medicinal plants through ancient ages until now are gaining a global attention, because traditional medicines are effective and easily available alternate to pharmaceuticals. Medicinal plants are used around the world as therapy for different diseases (Cushnie et al 2014). Endophytic bacteria colonize with medicinal plants offers progress survival strategies to improve plant growth, rise up resistance to abiotic and biotic stresses, facilitate nutrient uptake and consolidate systemic resistance and paly a great role as biocontrol agents for many plant diseases (Daffonchio et al 2015). Which, offer an opportunity to always be in contact with the plant's tissue so, more easily present a direct benefit effects on plant host. This study aimed to isolation, classification and characterization of plant growth promoting potential endophytic bacteria from some medicinal plant.

\section{MATERIAL AND METHODS}

\subsection{Plant samples and bacterial endophytic isolation}

Seven healthy green medicinal plants were collected from Giza government; Coriandrum sativum, Anethum graveolens, Pelargonium graveolens, Ocimum basilicum, Rosmarinus officinalis, Saliva officinalis and Origanum majorana. The plant roots and leaves were used to isolate the endophytic bacteria by followed two techniques.

\subsection{Isolation of endophytic bacteria}

The plant samples $(1 \mathrm{~cm}$ pieces) were washed by running tap water with two drops of tween 20 (as wetting agent) then surface sterilized by ethanol $70 \%$ for $2 \mathrm{~min}$, followed by sodium hypochlorite $2 \%$ for $1 \mathrm{~min}$. Finally, they were washed in sterile distilled water for 3 times and drying in sterilized filter paper under aseptic conditions (laminar air flow) the last washing distilled water was plated onto nutrient agar and potato dextrose agar media and then incubated at $28^{\circ}-30^{\circ} \mathrm{C}$ for $2-5$ days to confirm that the surface of plant pieces were effectively decontaminated. The plant surface sterilized plant samples (1 $\mathrm{cm}$ pieces) placed on nutrient agar medium, incubated at $28^{\circ}-30^{\circ} \mathrm{C}$ for 5 days. While the second technique were carried out by macerated the surface sterilized plant in $10 \mathrm{ml}$ of saline solution. Serial dilutions were performed till reached $10^{3}$. Individual colonies were picked up, purified and microscopically examined for morphological characteristics. Isolates were maintained on the same media at $4^{\circ} \mathrm{C}$. Sub-culturing of the purified isolates was monthly done.

\subsection{Assesment of potential plant beneficial traits}

\subsubsection{Screening for enzymes activity}

Endophytic bacterial isolates were screened for cellulase, pectinase and amylase activities by growing the each one individually on carboxymethylcellulose medium (Ray et al 2007), pectin screening agar medium (PSAM) (Raju and Divakar, 2013) and nutrient agar medium supplemented with $1 \%$ soluble starch (Fouda et al 2015) respectively. The appearance of clear halo around colonies indicated on enzymes production, the substrate solubization of enzyme was expressed as the following equation: solubilizing index= colo$\mathrm{ny}+$ halo diameter/ colony diameter $(\mathrm{mm})$.

\subsubsection{Phytochemical screening in endopyhtic bacterial culture}

The extract culture filtrate was subjected to phytochemical screening for the determination of some metabolites like; indole acetic acid, gibberellins, antioxidants activity, phenols, alkaloids and flavonoids as follows.

\subsubsection{Indole acetic acid (IAA) assay}

The ability of endophytic isolates to produce indole acetic acid was qualitatively assayed by growing the tested isolates on nutrient agar medium supplemented by $1 \mathrm{mM}$ tryptophan for 3 days $/ 28^{\circ}$ $30^{\circ} \mathrm{C}$. While the quantitative assay was performed in culture supernatant by the colorimetric technique using Salkowski reagent as described by Bric et al (1991). 


\subsubsection{Gibberellins determination}

The total gibberellins content in extracts were determined spectrophotometrically according to the method of Udagwa and Kinoshita (1961). Gibberellic acid was used as a standard curve.

\subsubsection{Antioxidant assay}

The free radical scavenging DPPH assay was used to evaluate the antioxidant potential of endophytic bacterial extract. The inhibition percent of free radical formation ( $1 \%$ ) was determined in one $\mathrm{ml}$ of cell free bacterial culture using standard method as described by Burits and Bucar (2000) and was calculated by the following formula

$$
I \%=\left(A_{\text {blank }}-A_{\text {sample }} / A_{\text {blank }}\right) \times 100
$$

Where: $A$ blank is the absorbance of the control reaction (containing all reagents except the test compound) and $A$ sample is the absorbance of the test compound.

\subsubsection{Total phenols}

Determination of total phenols in cell free culture of selected endophytic bacterial isolates using a colorimetric method described by Yadav et al (2014). Gallic acid was used as a standard curve.

\subsubsection{Alkaloids content}

Total alkaloids were assayed in cell free culture were carried out according to Shamsa et al (2008) after the centrifugation at $10000 \mathrm{rpm}$ for $20 \mathrm{~min}$. under cooling condition ( $1 \mathrm{ml}$ of cell free culture added to $5 \mathrm{ml}$ phosphate buffer solution $+1 \mathrm{ml}$ of bromocresol green solution and shacked the mixture with $10 \mathrm{ml}$ of chloroform in separator funnel) the absorbance of the complex in chloroform was measured at $578 \mathrm{~nm}$. Atropine was used as a standard curve.

\subsubsection{Flavonoids content}

The total flavonoids content in free cell cultures of tested isolates were determined by spectrophotometry according to the method of Christel et al (2000). Quercetin equivalent was used as a standard curve. The content of flavonoids was expressed in milligram per milliliter of quercetin equivalent.

\subsection{Screening for bio-control activity}

\subsubsection{Antifungal activity}

The endophytic bacterial isolates were used to estimate their inhibition effect against four soil born pathogenic fungi (Fusarium oxysporium B27, Fusarium solani B99, Rhizoctonia solani Z7 and Sclerotium rolfsii B20) separately, using dual culture method (Skidmore and Dickinson, 1976) on potato dextrose plates. The pathogenic fungal cultures were obtained from plant protection department, agriculture research center, Giza, Egypt. Antifungal activity was calculated as \% fungal growth reduction according to Vincent (1927) by the following formula $X=100-[G 2 / G 1$ *100] where, $X=\%$ of reduction in growth ( $G 1=$ growth of pathogenic fungus in control plates) $(G 2=$ growth of pathogenic fungus in dual plates with bacterial isolates).

\subsubsection{HCN production}

The most efficient isolates were cultured individually in nutrient broth medium, supplemented with $4.4 \mathrm{~g} / \mathrm{l}$ glycine to detect HCN production; the development of yellow to dark brown color after incubation period indicated HCN production (Bakker and Schippers, 1987).

\subsection{Screening for nutrients availability}

\subsubsection{Ammonia production}

The selected endophytic bacterial isolates were tested for their ability to produce ammonia using Nesseler's reagent after the incubation period for isolates in peptone broth medium. Whereas the positive result observed in change of color to faint yellow (small amount of ammonia) deep yellow to brown (indicated maximum ammonia production) according to Singh et al (2014).

\subsubsection{Siderophores production}

The amount of siderophores was determined by modified CAS (chrome Azurol S) assay solution method (Alexander and Zuberer, 1991).

\subsubsection{Nitrogenase activity}

Nitrogenase activity was determined separately by the method of acetylene reduction technique according to standard method described by Dilworth (1966). Results were calculated as Nmole $\mathrm{C}_{2} \mathrm{H}_{4} / 100 \mathrm{ml} / \mathrm{h}$. 


\subsubsection{Phosphate solubilization activity}

The efficient endophytic bacterial isolates were examined individually for their potential to solubilize tricalcium phosphate on Pikovskaya's broth medium (Subba Rao, 1982). The amount of soluble phosphate was determined by spectrophotometry in culture filtrates according to Jackson (1967).

\subsection{Localization of endophytic bacteria within plant tissue}

\subsubsection{Vital staining Technique using spermsphere model}

Seed of two medicinal plants (Ocimum basilicum and Coriandrum sativum) were used to detect the colonization of six most efficient isolates within their root tissue by two methods. Ocimum basilicum (basil) and Coriandrum sativum (coriander) seeds were obtained from Faculty of Agriculture, Cairo University, Giza, Egypt and El-Korma Egyptian company for seeds, oils and chemicals, respectively. The seeds were washed under tap water in presence of two drops of tween 20 as wetting agent for 10 minutes and surface sterilization was done using ethanol alcohol for 30 second then rinsed thoroughly under aseptic condition in sterile distilled water following by soaking in $20 \%$ sodium hypochloride for 15 minutes. Finally washed three times in sterile distilled water and put them in a petri dish on a filter paper 10 minutes to dry until seed culture. Basil seeds were aseptically cultured in perti dish contain $30 \mathrm{ml}$ of MS medium without any growth regulators (Murashige and Skoog, 1962). In the other hand coriander seeds germination was done on sterilized Jars contain 2.5 gram cotton wetted with $50 \mathrm{ml}$ distilled water, every jar contain 5 seeds. After the five days of germination for basil and coriander seeds; spermsphere model was used as described by Thomas-Bauzon et al (1982) to detect the colonization. The most efficient isolates were cultured in $50 \mathrm{ml}$ nutrient broth under shaking condition $200 \mathrm{rpm}$ at $30^{\circ} \mathrm{C}$ for $48 \mathrm{~h}$, after the incubation period $0.5 \mathrm{ml}$ of bacterial culture $\left(10^{8} \mathrm{CFU} / \mathrm{ml}\right)$ individually was inoculated to the spermsphere model which contain the germinated seeds of medicinal plant, followed by an incubation period ( 5 days) to be sure that the colonization occurred. In the last day of the incubation period, the roots of basil and coriander in spermsphere model treated with 2,3,5 triphenyl tetrazolium chlo- ride ( $2 \mathrm{ml}$ TTC solution /sample) for $3 \mathrm{~h}$ to detect the colonization by change the root color to red.

\subsubsection{Transmission electron microscope exam- ination}

Microscopic visualization using transmission electron microscopy (TEM) was performed to observe the colonization of endophytic bacterial isolates in the roots (with red color after treated with TTC solution) by JEOL-JEM-2100 TEM.

\subsection{Phenotypic characteristics of endophytic bacteria}

Microscopic and biochemical characterization were performed to classify the bacterial isolates; gram reaction and endospore staining, motility, catalase, oxidase activity, colony shape, producing of diffusible pigment and fluorescent pigmentation on nutrient and king's media.

\subsection{Hypersensitivity test}

HR test is used as a quick and useful determinative test to identified saprophytes from plant pathogens. The suspensions of endophytic bacteria were prepared individually in nutrient broth medium, for $24 \mathrm{~h}$ at $28-30^{\circ} \mathrm{C}$ and adjusted to $10^{8} \mathrm{CFU} /$ $\mathrm{ml}$ using a JASCO V-630 spectrophotometer. The bacterial suspension $200 \mu \mathrm{l}$ was injected into the abaxial surface of the lower epidermis of Capsicum annuum leaves using a syringe without a needle. Every isolates suspension injected into three leaves as a replicates, while the control plant injected its leaves with distilled water. The treated plants were grown in a greenhouse under control condition (Wai et al 2015).

\section{RESULTS AND DISCUSSION}

\subsection{Isolation of endophytic bacteria}

Endophytic microorganisms (bacteria and fungi) have been found in every plant species (Gustavo et al 2016). 89 endophytic bacterial isolates were isolated by followed two techniques from surface sterilized roots of seven medicinal plants, the selected plants were found to harbor a variety of endophytic bacteria. The distribution percentages of collected bacterial isolates associated with the roots of the tested plants was given in Fig. (1). The 
highest percentage of collected isolates being $21.34 \%$ followed by $19.1 \%$ and $17.97 \%$ were detected from the roots of Rosmarinus officinalis, Pelargonium graveolens and Ocimum basilicum, respectively. The pure single isolated colonies were picked up on the basis of their cultural and morphological characteristics. Endophytic bacterial isolates were belonged to two bacterial groups, 53 isolates long rods whereas 36 isolates short rods. The variety of endophytes within the tissue based on the distribution of rhizospheric PGPB in nature according to Timmusk et al (2011). The plant endo-rhizosphere niche comprises a diverse population of bacterial taxa (endophytic bacteria) which may detrimental or beneficial to the associated plant (Ullah et al 2018).

\subsection{Preliminary screening of PGP traits for en- dophytic isolates}

All endophytic bacteria isolated from tested plants were screened for multi plant growth promoting traits in order to obtain promising endophytic bacteria

\subsubsection{Enzymatic activity}

Endophytic bacteria secreted extracellular enzymes as a tool to penetrate and colonize inside the tissue of host plant. In the present study all the 89 endophytic bacterial isolates were screened for cellulase, pectinase and amylase activities. The plates which the colonies showed clear zone around it was selected as a producer for extracellular enzymes Fig. (2), then the enzymes activity was calculated and represented as solubilizing index. Out of 89 bacterial isolates, 44 isolates (31 long rods- 13 short rods) can hydrolysis the CMC, 36 isolates (26 long rods- 10 short rods) can produce pectinases enzymes, also 28 isolates (24 long rods- 4 short rods) gave positive result for starch solubilization. The result is similar to Egamberdieva et al (2017) who reported that endophytic bacteria isolated from the medicinal plants Ferula songorica, Hypericum perforatum, and Ziziphora capital could secrete different hydrolytic enzymes including cellulase, protease, and amylase. Naveed et al (2014) demonstrated that endophytic bacteria may modify the cell wall of the plant by secreting cellulolytic enzymes (endoglucanase, cellulases and pectinases, which facilitate the entry and spread of bacteria with in plant. The lytic enzymes activities were recorded according to their solubilizing index into three ranks as demonstrated in Fig. (2 \& 3).

\subsubsection{Phytohormones production}

Ullah et al (2018) reported that, endophytic bacteria can promote plant health through synthesizing more than one of phytohormones auxins, gibberellins and cytokinins or by regulation the internal hormone levels in the host plant body leading to enhance plant growth by stimulate cell enlargement, differentiation and cell division. All the 89 endophytic bacterial isolates were screened for their ability to produce IAA qualitatively and determination the amount of $\mathrm{GA}_{3}$. Twenty two isolates produced IAA, while 82 isolates produced $\mathrm{GA}_{3}$. The ability of IAA production for positive isolates was varied from one isolate to another and expressed in three categories according to their efficacy, six shoet rods isolates gave the high potent of IAA, namely C4, C5, RO6, RO9, S2 and S14. Out of eighty two endophytic bacterial isolates produced $\mathrm{GA}_{3}$ in great variation which ranged from less than 12 to $22 \mathrm{ppm}$. From the preliminary screening, the highest twenty potent endophytic bacteria were selected for further studies.

\subsection{Secondary screening of endophytic as bio- control agent}

The secondary screening was carried out on twenty endophytic bacterial isolates which have the high potential of lytic enzymes, IAA and $\mathrm{GA}_{3}$ production. Endophytic bacteria offer a beneficial effect on their host plant as a biocontrol agent to prevent pathogenic to infect the plant. According to initial screening, the selected isolates showed multiple PGP traits and were assessment of their antagonistic effect against 4 pathogenic fungi (Fusarium oxysporium B27, Fusarium solani B99, Rhizoctonia solani $\mathrm{Z7}$ and Sclerotium rolfsii B20), results showed that isolates no. B3, S7, S14, D6 and $\mathrm{C} 8$ give the highest \% of growth reduction being $43.90 \%$ for isolates B3 \& S14 isolate and $39.02 \%$ for isolates S7, D6, C8 against Fusarium oxysporium B27 (Table 1). Isolate S14 and D2 recorded the highest percentage of growth reduction against Fusarium solani B99 being $46.94 \%$ and $43.90 \%$, respectively (Table 1). One isolate (S14) among 20 tested bacterial isolates gave antagonistic effect against Rhizoctonia solani Z7 being $28.04 \%$ growth reduction (Table 1 ). Isolates B3, D6 and RO10 show the greatest percentage of growth reduction against Sclerotium rolfsii B20 being $28.04 \%, 26.21 \%$ and 23.77 , respectively (Table 1). Diseases caused by fungal, viral, bacteria, insects and nematodes can be reduced by inoculation with endophytes (Berg and Hallmann, 2006). 


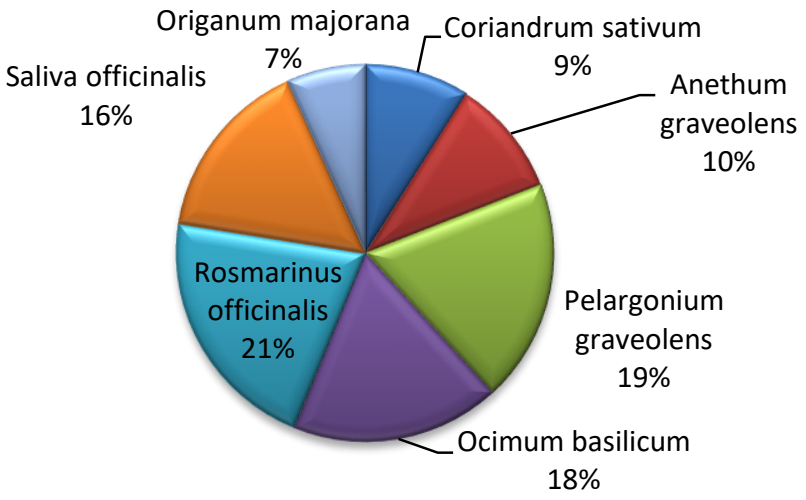

Fig. 1. The distribution percentage of endophytic bacterial cultures isolated from the roots of seven medicinal plants

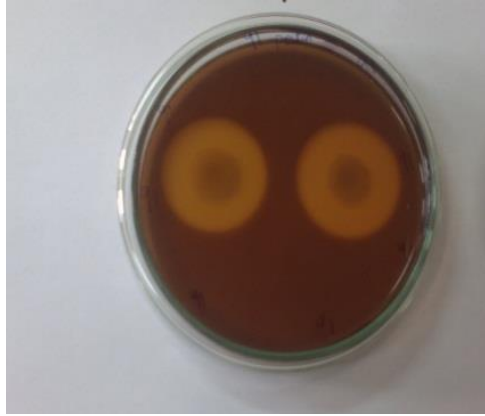

a

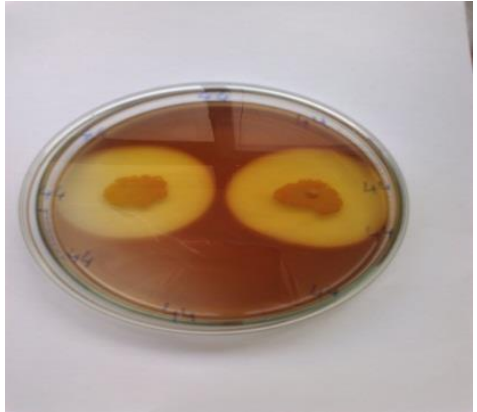

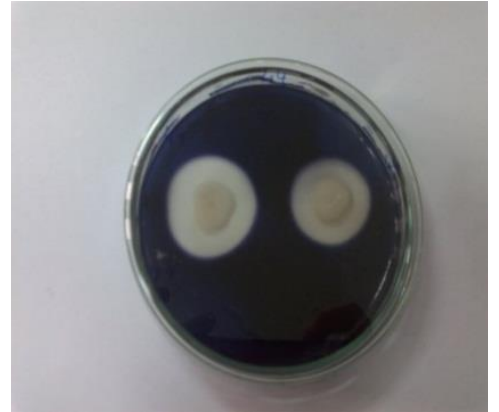

C

Fig. 2. Efficacy of hydrolysis enzymes produced by endophytic bacterial isolates on pectin, CMC and starch a) Pectin, b) CMC, c) starch

$$
1 \text { _ } 2 \text { 2.1_3 }>3
$$

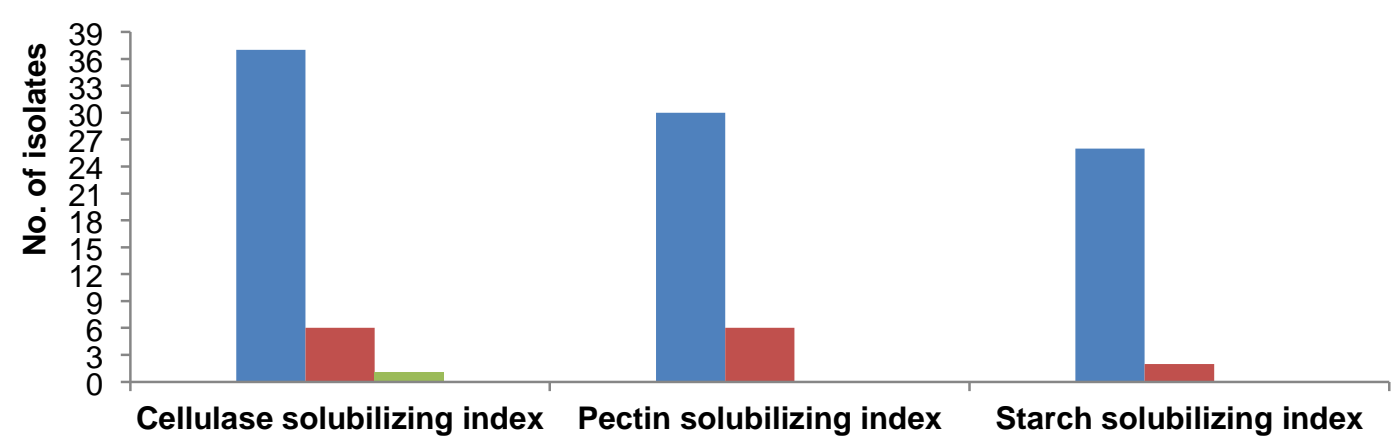

Fig. 3. Ranking of solubilizing index of extracellular enzymes produced by endophytic bacteria isolated from some medicinal plants 
Table 1. Antagonistic effect of endophytic bacterial isolates against four soil borne pathogenic fungi as well as ammonia and siderophores production

\begin{tabular}{|c|c|c|c|c|c|c|c|}
\hline \multirow[b]{2}{*}{$\begin{array}{c}\text { Morphological } \\
\text { shape }\end{array}$} & \multirow[b]{2}{*}{$\begin{array}{l}\text { Isolate's } \\
\text { code }\end{array}$} & \multicolumn{4}{|c|}{ Antagonistic effect } & \multirow[b]{2}{*}{$\begin{array}{c}\mathrm{NH}_{3} \\
\text { production }\end{array}$} & \multirow{2}{*}{$\begin{array}{l}\text { Amount of } \\
\text { siderophore } \\
{ }^{*}(\mathrm{mMDFOM})\end{array}$} \\
\hline & & $\begin{array}{c}\text { Fusarium } \\
\text { oxysporium } \\
\% \text { growth } \\
\text { reduction }\end{array}$ & $\begin{array}{l}\text { Fusarium } \\
\text { solani \% } \\
\text { growth } \\
\text { reduction }\end{array}$ & $\begin{array}{l}\text { Rhizoctonia } \\
\text { solani \% } \\
\text { growth } \\
\text { reduction }\end{array}$ & $\begin{array}{l}\text { Sclerotium } \\
\text { rolfsii \% } \\
\text { growth } \\
\text { reduction }\end{array}$ & & \\
\hline \multirow{13}{*}{ 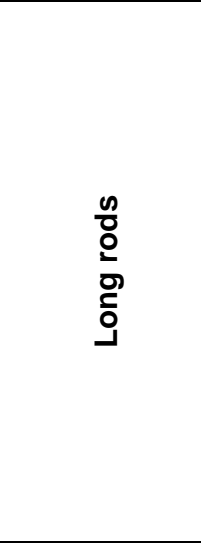 } & C3 & - & - & - & - & + & - \\
\hline & $\mathrm{C} 8$ & $39.02 \pm 0.3$ & $40.24 \pm 0.7$ & - & - & +++++ & $67 \pm 0.2$ \\
\hline & D2 & $34.75 \pm 0.3$ & $43.90 \pm 0.7$ & - & $26.21 \pm 0.5$ & +++ & $59 \pm 1.9$ \\
\hline & D6 & $39.02 \pm 0.7$ & - & - & $26.21 \pm 0.3$ & +++++ & $49 \pm 0.2$ \\
\hline & D9 & $34.14 \pm 0.7$ & - & - & - & + & - \\
\hline & R3 & - & - & - & - & + & - \\
\hline & R8 & - & - & - & - & + & - \\
\hline & $\mathrm{R} 11$ & - & - & - & - & ++ & - \\
\hline & R15 & - & - & - & - & +++++ & $67 \pm 0.3$ \\
\hline & B3 & $43.90 \pm 0.5$ & - & - & $28.04 \pm 0.4$ & +++ & $60 \pm 0.3$ \\
\hline & B11 & $26.82 \pm 0.6$ & - & - & $21.34 \pm 0.3$ & +++ & $68 \pm 0.2$ \\
\hline & M3 & - & $40.85 \pm 0.6$ & - & $28.04 \pm 0.3$ & ++++ & $66 \pm 0.2$ \\
\hline & M4 & $31.70 \pm 0.7$ & - & - & - & ++++ & $61 \pm 0.2$ \\
\hline \multirow{7}{*}{ 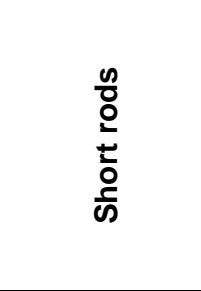 } & RO3 & - & - & - & - & - & - \\
\hline & RO6 & $37.8 \pm 0.7$ & $19.51 \pm 0.5$ & - & - & +++ & $62 \pm 0.2$ \\
\hline & R010 & $34.14 \pm 0.7$ & - & - & $23.77 \pm 0.8$ & ++++ & $49 \pm 0.2$ \\
\hline & R014 & $39.02 \pm 0.3$ & - & - & $23.16 \pm 0.7$ & +++++ & $66 \pm 0.3$ \\
\hline & S2 & - & - & - & - & - & - \\
\hline & S7 & $39.02 \pm 0.3$ & $22.56 \pm 0.3$ & - & - & +++++ & $38 \pm 0.3$ \\
\hline & $\mathrm{S} 14$ & $43.90 \pm 0.7$ & $46.94 \pm 0.5$ & $28.04 \pm 0.7$ & $28.65 \pm 0.3$ & +++ & $67.5 \pm 0.2$ \\
\hline
\end{tabular}

${ }^{*} \mathrm{mMDFOM}=\mathrm{mM}$ deferoxamine mesylate

To estimate the endosymbiotic of the tested endophytes bacterial isolates, data presented in Table (2) recorded that $15 \%$ of the isolates (B3, M3 and M4) were superior in antioxidant activity which ranged between $18.53 \%$ - $64.50 \%$. Data in Table (2) revealed that isolate D6 was found to have potential for use as antioxidant, since it produced highest figure of phenols being $22.38 \mathrm{ppm}$ gallic acid equivalent. As regards to IAA production, data represented that the high potent were produced by $15 \%$ of the isolates (RO6, S2, S14) and ranged between 6.37 and 8.84 ppm, which recommended to use it in order to stimulate root formation and cell division in normal and harsh environmental condition. Yadav et al (2014) found that a high concentration of phenols produced from chaetomium sp. $(60.13 \pm 0.41 \mathrm{mg}$ gallic acid equivalent) followed by Aspergillus niger. As well as the $36 \%$ of fungal extracts showed significant antioxidant activity ranged from $50 \%$ to $80 \%$. Zhou and Chen (2006) reported that four endophytic fungi isolates isolated from a medicinal plant $(D i-$ oscorea opposite), gave strong antioxidant activity. Also Spaepen et al (2007) demonstrated that many endophytic bacteria species including Serratia sp., Enterobacter sp., Azotobacter sp. and Klebsiella produced IAA.

All the 20 selected isolates gave positive result for $\mathrm{NH}_{3}$ production except isolates $\mathrm{RO} 3$ and $\mathrm{S} 2$ (Table 1). C8, D6, R15, RO14 and S7 isolates recorded the highest efficient for $\mathrm{NH}_{3}$ production $(+++++)$. Ullah et al (2018) described that the endophytic bacteria, which has the ability to produced ammonia may able to enhancing the plant growth as a result of fix nitrogen atmosphere to ammonia, as well as ammonia is available nutrient source for plant growth. Endophytic bacteria can breakdown the complex nitrogenous materials and convert it into ammonia an available nitrogen source. In addition formation of ammonia changes the conditions to alkaline, which have a great role to suppress the pathogenic fungi growth according to Sansanwal et al (2018). For siderophores production, fourteen isolates out of the 20 selected 
Table 2. Quantity assessment of antioxidant, total phenols, indole acetic acid production and nitrogenase activity by the selective endophytic bacterial isolates

\begin{tabular}{|c|c|c|c|c|c|}
\hline $\begin{array}{l}\text { Morphological } \\
\text { shape }\end{array}$ & $\begin{array}{l}\text { Isolate's } \\
\text { code }\end{array}$ & $\begin{array}{c}\text { \%Antioxidant } \\
\text { activity }\end{array}$ & $\begin{array}{l}\text { Total phenols } \\
\text { (ppm) }\end{array}$ & $\begin{array}{c}\text { IAA } \\
(\mathrm{ppm})\end{array}$ & $\begin{array}{c}\text { Nitrogenase } \\
\text { Nmole } \mathrm{C}_{2} \mathrm{H}_{4} / 100 \\
\mathrm{ml}^{-1} \mathrm{~h}^{-1}\end{array}$ \\
\hline 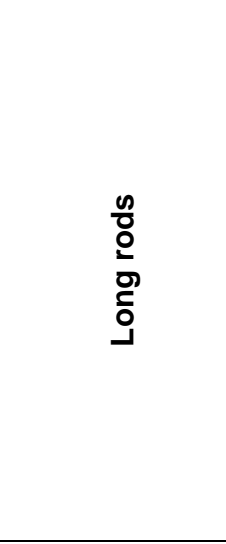 & $\begin{array}{c}\text { C3 } \\
\text { C8 } \\
\text { D2 } \\
\text { D6 } \\
\text { D9 } \\
\text { R3 } \\
\text { R8 } \\
\text { R11 } \\
\text { R15 } \\
\text { B3 } \\
\text { B11 } \\
\text { M3 } \\
\text { M4 } \\
\end{array}$ & $\begin{array}{c}- \\
49.22 \pm 0.2 \\
57.69 \pm 0.1 \\
55.62 \pm 0.3 \\
22.05 \pm 0.2 \\
18.53 \pm 0.3 \\
- \\
19.57 \pm 0.3 \\
41.03 \pm 0.2 \\
64.50 \pm 0.2 \\
35.30 \pm 0.2 \\
59.02 \pm 0.3 \\
57.97 \pm 0.2\end{array}$ & $\begin{array}{c}- \\
10.83 \pm 0.2 \\
9.38 \pm 0.3 \\
22.38 \pm 0.3 \\
- \\
- \\
- \\
- \\
10.64 \pm 0.2 \\
8.25 \pm 0.3 \\
7.95 \pm 0.3 \\
12.51 \pm 0.3 \\
8.25 \pm 0.3\end{array}$ & $\begin{array}{c}- \\
- \\
0.71 \pm 0.08 \\
- \\
- \\
- \\
- \\
- \\
- \\
- \\
- \\
0.32 \pm 0.05 \\
0.29 \pm 0.03\end{array}$ & $\begin{array}{c}- \\
6 \pm 0.2 \\
- \\
- \\
- \\
- \\
- \\
- \\
4 \pm 0.15 \\
- \\
- \\
4 \pm 0.16 \\
- \\
\end{array}$ \\
\hline $\begin{array}{l}\frac{n}{0} \\
\frac{0}{2} \\
\frac{1}{0} \\
\frac{0}{\omega}\end{array}$ & $\begin{array}{c}\text { RO3 } \\
\text { RO6 } \\
\text { RO10 } \\
\text { RO14 } \\
\text { S2 } \\
\text { S7 } \\
\text { S14 }\end{array}$ & $\begin{array}{c}- \\
38.24 \pm 0.3 \\
44.04 \pm 0.2 \\
30.90 \pm 0.3 \\
- \\
31.90 \pm 0.3 \\
26.48 \pm 0.2\end{array}$ & $\begin{array}{c}- \\
5.45 \pm 0.2 \\
- \\
6.85 \pm 0.2 \\
- \\
3.51 \pm 0.1 \\
7.39 \pm 0.2\end{array}$ & $\begin{array}{c}- \\
7.69 \pm 0.15 \\
3.37 \pm 0.03 \\
2.74 \pm 0.08 \\
6.37 \pm 0.16 \\
- \\
8.84 \pm 0.18\end{array}$ & $\begin{array}{c}- \\
- \\
- \\
12 \pm 0.2 \\
- \\
- \\
-\end{array}$ \\
\hline
\end{tabular}

isolates produced different amount of siderophores ranged from 38- $67.5 \mathrm{mM}$ deferoxamine mesylate (mMDFOM). The isolates C8, R15, B11, S14 and M3 recorded the highest values of siderophore production ranges from 66-68 mMDFOM. The results are in similar to the study done by Ramanuj and Shelat (2018) reported that the ability of bacterial endophytic isolated from medicinal plants to produce siderophore. Four isolates (RO14, C8, $\mathrm{R} 15$ and M3) out of the 20 selected isolates had nitrogenase activity giving $12,6,4$ and 4 $\mathrm{NmoleC}_{2} \mathrm{H}_{4} / 100 \mathrm{ml} / \mathrm{h}$, respectively (Table 2). Li et al (2018) found that $76 \%$ of isolates collected from natural arid habitats in xinjiang province of China can fix nitrogen. Furthermore bacterial endophytic within internal plant tissue, which offer a favorable environment for $\mathrm{N} 2$ fixation including minimize competition with other microorganisms in rhizosphere, also provide a micro aerobic condition, which is necessary for nitrogenase activity (Doty, 2017).

\subsection{Screening for phytochemical compound}

Endophytic microorganisms are excellent sources of novel bioactive compounds flavonoids, alkaloids and other bioactive compound. According to the previous PGP activities, six endophytic bacterial isolates (RO10, RO14, S14, D6, C8 and B3) were selected because of their efficiently for PGP activities. The selected endophytic isolates were tested for producing flavonoids, alkaloids, hydrogen cyanide and phosphate solubilization. There was a wide range of total flavonoids concentration in endophytic bacterial supernatant as shown in Table (3). The values varied from 1.43 to 31.14 ppm. The highest concentration of flavonoids was observed in cell free culture of isolates RO14 followed by isolate B3, whereas D6 recorded the lowest value. While the alkaloids production was detected by all the tested isolates except isolate S14. Isolate B3 gave the maximum alkaloids concentration in its supernatant being $0.34 \mathrm{ppm}$. Min et al (2010) found that strains ST22 (Aspergillus 
nidulans) and SX (Aspergillus oryzae) isolated from Ginkgo biloba L. twigs were able to produce flavonoids and phenolic compound. Phosphorus plays an important role in many plant processes (photosynthesis, nucleic acid synthesis, energy generation, cell signaling and respiration (Vance et al 2003). Four isolates out of the six most efficient isolates are able to solubilize phosphate. Table (3) show low variations between tested isolates in phosphate solubilization ranged from $5.65 \mathrm{ppm}$ by isolate RO14 to $3.85 \mathrm{ppm}$ by isolate C8. As a result, inoculation with the six most efficient isolates can increase phosphorus uptake by the plants. Phosphate solubilization technique revealed that isolates D6 and B3 can't solubilize insoluble phosphate. Bacterial endophytes are able to promote plant growth indirectly through suppressive the growth of phytopathogens by secreting anti- microbial substance as $\mathrm{HCN}$. The tested isolates gave no change in the filter paper color, so the six isolates showed negative result for HCN production (Table 3).

\subsection{Colonization of endophytic inside the root tissue}

\subsubsection{TTC stain technique}

2,3,5-triphenyl tetrazolium chloride (TTC) is colorless in the oxidized form and red when reduced by microorganisms, due to formation of formazan (triphenyl formazan (TPF) through enzymatic action (Vanerli et al 1999). The six most efficient isolates (RO10, RO14, S14, D6, C8 and B3) were tested on basil and coriander plants individually to detect the colonization of the tested bacteria in plant roots by using spermsphere model. All the six isolates gave positive result with basil and coriander plants, which appeared in change of roots color to red comparing to control which indicated that the tested bacteria colonized inside the plant root tissues of basil and coriander plants, whereas the control without bacteria showed no change of root tissue (Fig. 4). The results of this study is in line with Yachana and Subramanian (2012) studied the colonization of Paddy roots association bacteria in vivo by using TTC stain to visualize the bacteria in root cortex region.

\subsubsection{Transmission electron microscope exam-} ination (TEM)

Endophytic bacteria always prefer to occupy intercellular spaces in the host plant, because these areas have a plenty amount of carbohydrates, inorganic nutrients and amino acids. To address this point, images obtained by TEM showed the endophytic bacteria on surface and colonize intercellular space and intracellular the cortex tissue of two medicinal plants (basil and coriander) Fig. (5). Colonization by endophytes can be local at tissue level or systematic in the plant body; in the early stages of endophytes colonization were first observed in root hairs as follow in the root cortex (Rangjaroen et al 2017). So, this investigation confirmed the endophytic nature of tested bacterial isolates.

\subsection{Phenotypic characteristics}

Based on some morphological and biochemical characteristics of the most efficient isolates (RO10, $\mathrm{RO14}, \mathrm{S} 14, \mathrm{D} 6, \mathrm{C} 8$ and B3); the six isolates were similar to three genera (Enterobacter sp., Aeromonas sp. and Bacillus sp.). They are Aeromonas sp. R010, Aeromonas sp. R014, Enterobacter sp. S14, Bacillus sp. D6, Bacillus sp. C8 and Bacillus sp. B3). A large number of endophytic bacteria related to genus Enterobacter sp., Pseudomonas sp., Klebsiella sp., Alcaligenes sp., Bacillus sp. and Serratia have been found to enhance plant growth (Malfanova et al 2013).

\subsection{Hypersensitivity test}

Hypersensitivity test proved that all the six endophytic bacterial isolates (RO10, RO14, S14, D6, C8 and B3) are nonpathogenic bacteria. Where, these isolates gave negative symptoms of hypersensitivity reaction (HR) test on the pepper plants (Capsicum annuum) used as indicator plant. When the bacterial suspension was infiltrated into the abaxial surface of the lower epidermis of pepper plant leaves Fig. (6). Our results are similar to a study done by Wai et al (2015) on Capsicum sp. peppers in Korea. Stall et al (2009) observed that all phytopathogenic bacteria could produce a hypersensitive reaction in leaves mesophyll tissue, while the Saprophytes bacteria do not present this reaction. Hypersensitive test could recognize by necrosis led to change in the color of leaves in injection site from dark green to yellow then turned to light black within 24 hours. The further study was performed to screen these isolates according to their efficiency for induced systemic resistance and identified genetically of the efficient isolates. 
Table 3. Hydrogen cyanide, phosphate solubilization and bioactive compounds produced by endophytic bacterial isolates

\begin{tabular}{|c|c|c|c|c|c|}
\hline $\begin{array}{c}\text { Morphological } \\
\text { shape }\end{array}$ & $\begin{array}{c}\text { Isolate's } \\
\text { code }\end{array}$ & HCN & $\begin{array}{c}\text { Soluble phosphate } \\
\text { (ppm) }\end{array}$ & $\begin{array}{c}\text { Flavonoids } \\
\text { (ppm) }\end{array}$ & $\begin{array}{c}\text { Alkaloids } \\
\text { (ppm) }\end{array}$ \\
\hline \multirow{3}{*}{ Long rods } & C8 & - & $3.85 \pm 0.2$ & $5.68 \pm 0.19$ & $0.23 \pm 0.02$ \\
& D6 & - & - & $1.43 \pm 0.07$ & $0.22 \pm 0.02$ \\
& B3 & - & - & $16.10 \pm 0.3$ & $0.34 \pm 0.02$ \\
\hline \multirow{3}{*}{ Short rods } & RO10 & - & $5.05 \pm 0.2$ & $10.09 \pm 0.2$ & $0.23 \pm 0.02$ \\
& RO14 & - & $5.65 \pm 0.2$ & $31.14 \pm 0.3$ & $0.24 \pm 0.01$ \\
& S14 & - & $4.35 \pm 0.2$ & $9.80 \pm 0.3$ & - \\
\hline
\end{tabular}

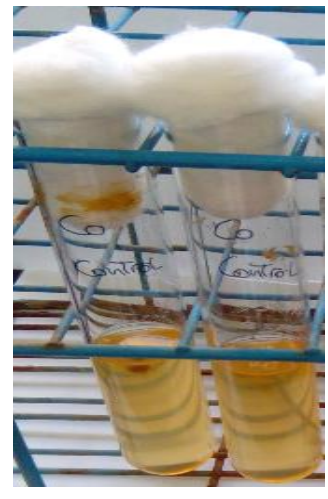

a) control

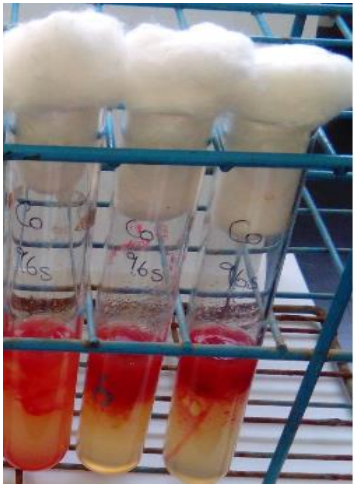

b) $\mathrm{S} 14$

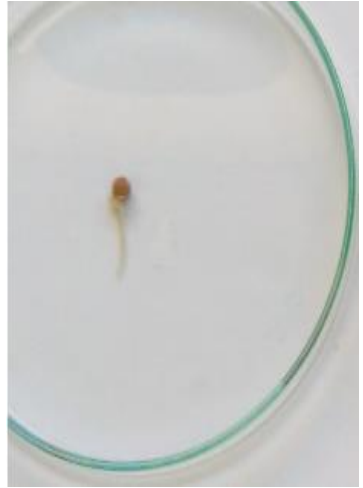

c) Control

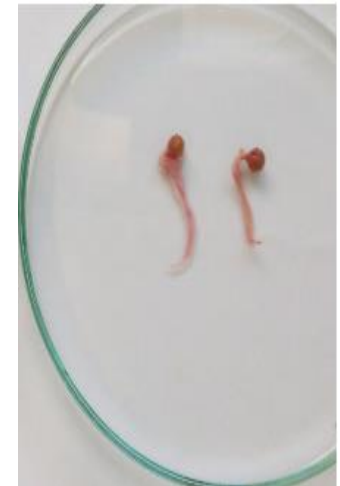

d) S14

Fig. 4. Coriander root plant treated with TTC stain (a \& c control) (b \& d inoculated roots)

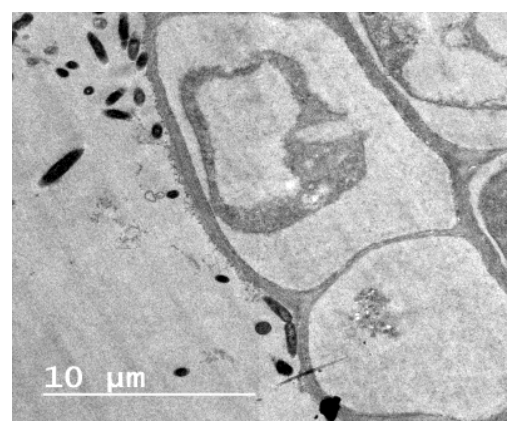

a

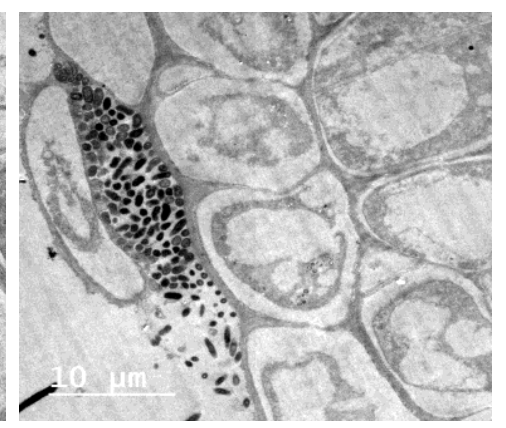

b

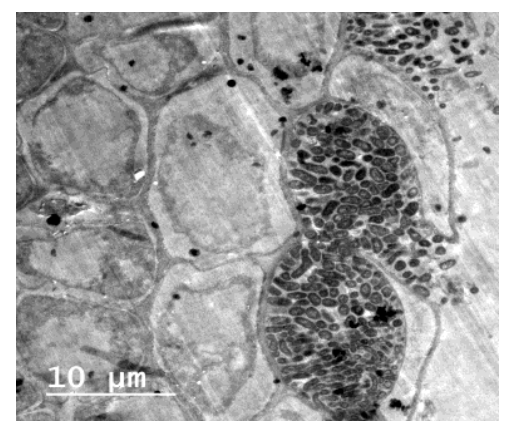

Fig. 5. Images by transmission electron microscope of Coriander seedling root tissue stained by TTC stain after four days of inoculation showing the distribution of bacterial cells in cortical region. a) on surface, b) intercellular space and d) intracellular 


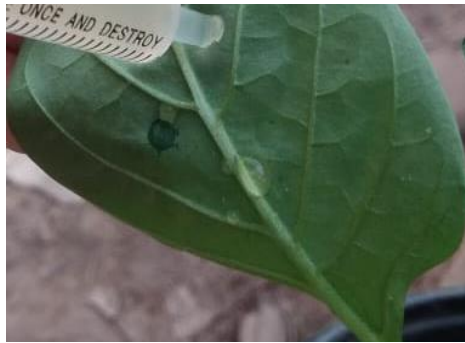

Bacterial suspension injection

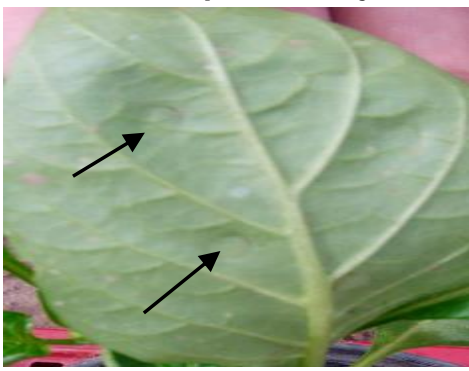

$48 \mathrm{~h}$

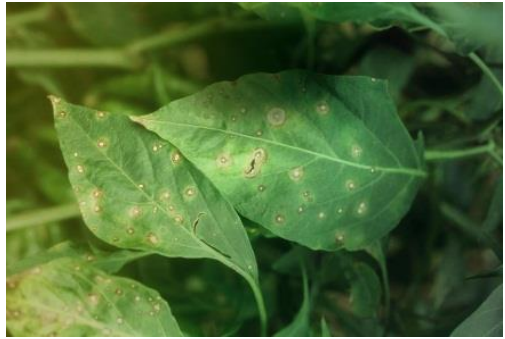

+ HR reaction

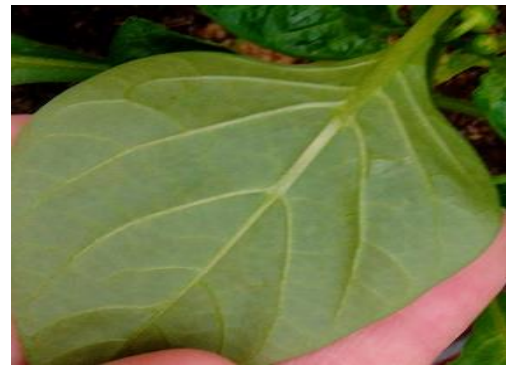

3 days

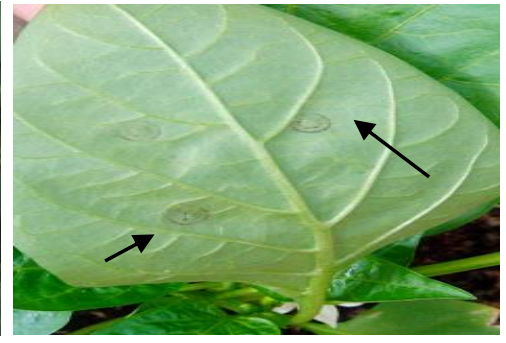

$24 \mathrm{~h}$

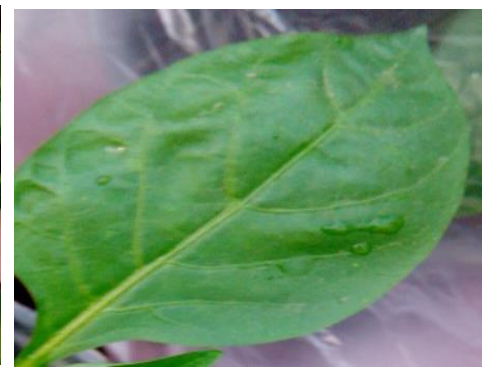

7days

Fig. 6. Hypersensitivity test on pepper plant (Capsicum annuum) injected by tested endophytic bacteria during 7 days under greenhouse conditions (black arrows refer to injection sites)

\section{CONCLUSION}

The present study represents the distribution and bioactivity of endophytic bacteria associated with some medicinal plants. The selected endophytic bacteria have the potential to colonize plant root and interact beneficially with the host plant. The selected bacteria produced different hydrolytic enzymes (cellulase, pectinase and amylase), which may play an important role in initial plant infection. As well as, they showed various abilities related to plant growth promoting including; solubilization of phosphate, production of phytochemical substance, ammonia, siderophores production, nitrogen fixation and were able to inhibit some pathogenic fungi. Tested bacteria were visualized using TEM inside its natural niche plant tissue to confirm their potentiality of colonization. These endophytic bacterial isolates were classified based on their morphological and biochemical characteristics to Aeromonas sp. R010, Aeromonas sp. R014, Enterobacter sp. S14, Bacillus sp. D6, Bacillus sp. C8 and Bacillus sp. B3, which are saprophytic bacteria.

\section{REFERENCES}

Alexander D.B. and Zuberer D.A. 1991. Use of Chrome Azurol $S$ reagents to evaluate siderophore production by rhizosphere bacteria. Biol. Fertil. Soils. 12, 39-45.

Aly A.H., Debbab A. and Proksch P. 2011. Fungal endophytes: unique plant inhabitants with great promises. Appl. Microbiol. Biotechnol. 90, 1829-1845.

Bakker A.W. and Schippers B. 1987. Microbial cyanide production in the rhizosphere in relation to potato yield reduction and Pseudomonas spp. mediated plant growth stimulation. Soil Biol. Biochem. 19, 249-256.

Berg G. and Hallmann J. 2006. Control of plant pathogenic fungi with bacterial endophytes, In: Microbial Root Endophytes. Schulz B.J.E., Boyle C.J.C. and Sieber T.N. (eds.), SpringerVerlag, Berlin, pp. 53-69.

Bric J.M., Bostock R.M. and Silverstone S.E. 1991. Rapid in situ assay for indole acetic acid production by bacteria immobilized on a nitrocellulose membrane. Appl. Environ. Microbiol. 57, 535-538. 
Burits M. and Bucar F. 2000. Antioxidant activity of Nigella sativa essential oil. Phytother. Res. 14, 323-328.

Christel Q.D., Gressier B., Vasseur J., Dine T., Brunet C., Luyckx M., Cazin M., Cazin J.C., Bailleul F. and Trotin F. 2000. Phenolic compounds and antioxidant activities of buckweat hulls and flour. J. Ethnopharmacol. 72, 35-42.

Cushnie T.T., Cushnie B. and Lamb A.J. 2014. Alkaloids: an overview of their antibacterial, antibiotic-enhancing and antivirulence activities. Int. Arab J. Antimicrob. Agents. 44, 377-386.

Daffonchio D., Hirt H. and Berg G. 2015. Plantmicrobe interactions and water management in arid and saline soils, In: Principles of plantmicrobe interactions. Lugtenberg B. (ed.), Springer, Cham. pp. 265-276.

Dilworth M.J. 1966. Acetylene reduction by nitrogen fixing preparations from Clostridium pasteurianum. Biochim. Biophys. Acta. 127, 285294.

Doty S.L. 2017. Endophytic N-Fixation: Controversy and a Path Forward, In: Functional Importance of the Plant Microbiome. Doty S.L. (ed.), Springer International Publishing, New York, USA, pp. 17-58.

Egamberdieva D., Wirth S., Behrendt U., Ahmad P. and Berg G. 2017. Antimicrobial activity of medicinal plants correlates with the proportion of antagonistic endophytes. Front Microbiol. 8, e199, pp. 1-11.

Fouda A.H., Hassan S.E.D., Eid A.M. and Ewais E.E.D. 2015. Biotechnological applications of fungal endophytes associated with medicinal plant Asclepias sinaica (Bioss.). Ann. Agric. Sci. 60, 95-104.

Gustavo S., Gabriel M.H., Ma D.O.M. and Bernard R.G. 2016. Plant growth-promoting bacterial endophytes. Microbiol. Res. 183, 92-99.

Hassan S.E. 2017. Plant growth-promoting activities for bacterial and fungal endophytes isolated from medicinal plant of Teucrium polium L. J. Adv. Res. 8, 687-695.

Jackson M.L. 1967. Soil chemical analysis. Prentice- Hall of India private limited, New Delhi, India. pp. 183-192.

Li L., Mohamed O.A.A., Ma J., Friel A.D., Su Y., Wang Y., Musa Z., Liu Y., Hedlund B.P. and Li W. 2018. Synergistic plant-microbe interactions between endophytic bacterial communities and the medicinal plant Glycyrrhiza uralensis F. Antonie Van Leeuwenhoek. 10, 1735-1748.
Malfanova N., Kamilova F., Validov S., Chebotar V. and Lugtenberg B. 2013. Is L-arabinose important for the endophytic lifestyle of Pseudomonas. Arch. Microbiol. 195, 9-17.

Min Q., Rui-sheng X., Yu S., Haihua Z. and Hai$\min$ C. 2010. Isolation and identification of two flavonoid-producing endophytic fungi from Ginkgo biloba L. Ann. Microbiol. 60, 143-150.

Murashige T. and Skoog F. 1962. A revised medium for rapid growth and bioassays with tobacco tissue culture. J. Plant Physiol. 15, 473497.

Naveed M., Mitter B., Yousaf S., Pastar M., Afzal M. and Sessitsch A. 2014. The endophyte Enterobacter sp. FD17: A maize growth enhancer selected based on rigorous testing of plant beneficial traits and colonization characteristics. Biol. Fertil. Soils. 50, 249-262.

Raju E.V.N. and Divakar G. 2013. Screening and Isolation of Pectinase producing Bacteria from Various Regions in Bangalore. Int. J. Res. Pharm. Biomed. Sci. 4, 151-154.

Ramanuj K.B. and Shelat H.N. 2018. Plant growth promoting potential of bacterial endophytes from medicinal plants. Advances in Research, 13, 1-15.

Rangjaroen C., Sungthong R., Rerkasem B., Teaumroong N., Noisangiam R. and Lumyong S. 2017. Untapped Endophytic Colonization and Plant Growth Promoting Potential of the Genus Novosphingobium to Optimize Rice Cultivation. Microbes Environ. 32, 84-87.

Ray A.K., Bairagi A.A., Ghosh K.S. and Sen S.K. 2007. Optimization of Fermentation Conditions for Cellulase Production by Bacillus Subtilis Cy5 and Bacillus Circulans Tp3 Isolated from Fish gut. Acta Ichthyol. Piscatoria. 37, 47-53.

Sánchez-López A.S., Thijs S., Beckers B., González-Chávez M.C., Weyens N., CarrilloGonzález R. and Vangronsveld J. 2017. Community structure and diversity of endophytic bacteria in seeds of three consecutive generations of Crotalaria pumila growing on metal mine residues. Plant Soil. 422, 51-66.

Sansanwal R., Ahlawat U., Batra P. and Wati L. 2018. Isolation and evaluation of multi-trait novel bacterial endophytes from root nodules of mungbean (Vigna radiata). Int. J. Curr. Microbiol. Appl. Sci. 7, 2424-2430.

Serpil S. 2012. An Agricultural Pollutant: Chemical Fertilizer. Int. J. Environ. Sci. Dev. 3, 77-80. 
Shamsa F., Monsef H., Ghamooshi R. and Verdian-rizi M. 2008. Spectrophotometric determination of total alkaloids in some Iranian medicinal plants. Thai J. Pharm. Sci. 32, 17-20.

Singh P., Kumar V. and Agrawal S. 2014. Evaluation of phytase producing bacteria for their plant growth promoting activities. Int. J. Microbiol. 6, 1-7.

Skidmore A.M. and Dickinson C.M. 1976. Colony interactions and hyphae interferences between Septoria nodorum and phylloplane fungi. Trans. Br. Mycol. Soc. 66, 57-64.

Spaepen S., Vanderleyden J. and Remans R. 2007. Indole-3-acetic acid in microbial and microorganism-plant signaling. FEMS Microbiol. Ecol. 31, 425-448.

Stella M. and Suhaimi M. 2010. Selection of suitable growth medium for free-living diazotrophs isolated from compost. J. Trop. Agric. Food Sci. 38, 211-219.

Subba-Rao N.S. 1982. Phosphate solubilizing micro-organisms: in Biofertilizers in Agriculture. Oxford and IBH Publication, New Delhi, India. pp. 126-136.

Thomas-Bauzon D., Weinhard P., Villecourt P. and Balandreau J. 1982. The spermosphere model. I. Its use in growing, counting, and isolating N2 fixing bacteria from the rhizosphere of rice, Can. J. Microbiol. 28(8), 922-928.

Timmusk S., Paalme V., Pavlicek T., Bergquist J., Vangala A., Danilas T. and Nevo E. 2011. Bacterial distribution in the rhizosphere of wild barley under contrasting microclimates. PLOS One. 6, e17968, pp. 1-7.

Udagwa K. and Kinoshita S. 1961. A colorimetric determination of gibberellin $\mathrm{GA}_{3}$.Part II. J. Agric. Chem. Soc. Jap. 35, 219-223.
Ullah A., Mushtaq H., Ali U., Hakim Ali E. and Mubeen S. 2018. Screening, isolation, biochemical and plant growth promoting characterization of endophytic bacteria. Microbiol. Curr. Res. 2, 24-30.

Vance C.P., Uhde-Stone C. and Allan D.L. 2003. Phosphorus acquisition and use: critical adaptations by plants for securing a nonrenewable resource. New Phytol. 157, 423-447.

Vanerli B, Marcia A.F.B., Julio C.D., Luis A.N., Juliana A.D., Elsa H.W.S. and Bernadette D.G.M.F. 1999. Frequency of 2,3,5triphenyltetrazolium chloride (TTC) non-reducing bacteria in pasteurized milk. Rev. Microbiol. 30, 137-140.

Vincent T.M. 1927. Distortion of fungal hyphae in the presence of certain inhibitors. Nature. 159, 850-856.

Wai K.P.P., Siddique M.I., Mo H.S., Yoo H.J., Byeon S.E., Jegal Y. and Mekuriaw A.A. and Kim, B.S., 2015. Pathotypes of Bacterial Spot Pathogen Infecting Capsicum Peppers in Korea. Plant Pathol. J. 31, 428-432.

Yachana J. and Subramanian R.B. 2012. Isolation of root associated bacteria from the local variety of rice gj-17. World Res. J. Geoinformatics. 2, 21-26.

Yadav M., Yadav A. and Yadav J.P. 2014. In vitro antioxidant activity and total phenolic content of endophytic fungi isolated from Eugenia jambolana Lam. Asian Pac. J. Trop. Med. 1, S256S261.

Zhou, S.L. and Chen, S.L., 2006. Antioxidative activity of endophytic fungal strain isolated from zingiber yam (Dioscorea zingiberensis). J. Microbiol. 26, 40-44. 


\begin{tabular}{|c|c|c|}
\hline & 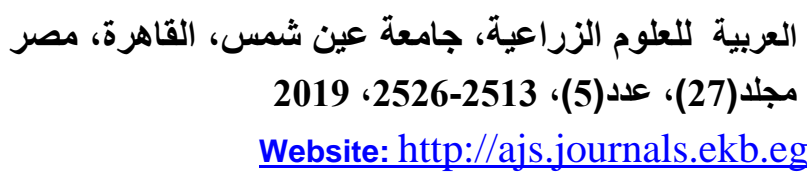 & 周 \\
\hline 2526 & & \\
\hline
\end{tabular}

توصيف البكتريا الداخلية المصاحبة لبعض النباتات الطبية

[199]

\author{
إيمان عادل سيد أحمد1"- إيناس عبد التواب حسن2 - كريم مصطفى كمال الطوبجى1 -

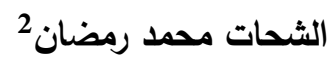 \\ 1- المعمل المركزى - معهد بحوث البساتين - مركز البحوث الزراعية - ص.ب. 12619 - جيزة - مصر

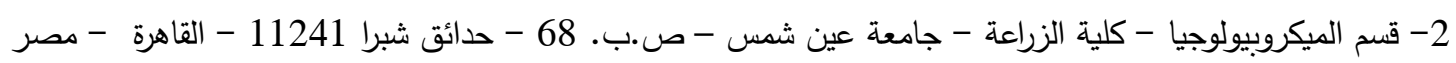

*Corresponding author: emadel21@yahoo.com

Received 3 October, 2019 Accepted 20 November, 2019

عزلة B3 أعلى إنتاجية من القلويدات 0.34 جزء فى وقلية المليون. وقد وجد أربع عزلات لهاتيا القدرة على إذابة

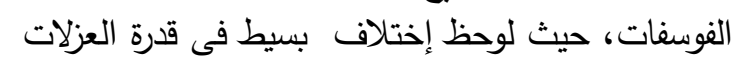
المختبرة لإذابة الفوسفات وتتراوح كمية الفوسفات الذائية الذية

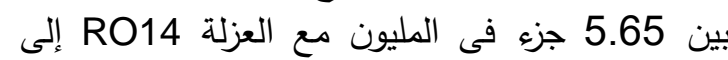

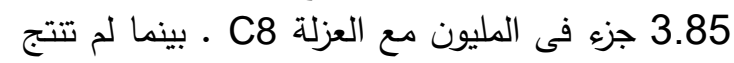

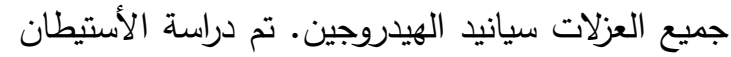
اللستة عزلات داخل النسيج النباتى لنوعين من النباتات النيات النيات الطبية وهما الريحان و الكزبرة بطريقتين مختلفتين؛ لألتاتئ

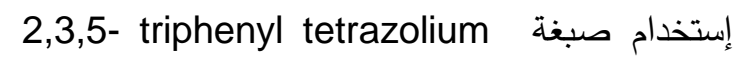
chloride على بعض الصفات المورفولوجية والفسيولوجية لتلتكانك عزلات (R10, RO14, S14, D6, C8, B3) تم الت Enterobacter sp., تصنيفها إلى 3 أجناس وهى Aeromonas sp. and Bacillus sp. أختبار الحساسية أن كل العزلات البكترية الاخلية هى

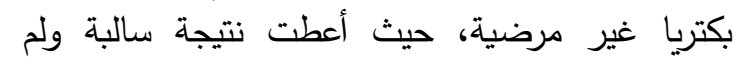
تظهر أعراض حساسية على نباتات الفلفل المستخدم كنبات كثاف.

الكلمات الدالة: البكتريا الداخلية، نباتات طبية،

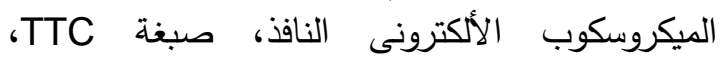
أستيطان الميكروبات الداخلية، عوامل PGP.

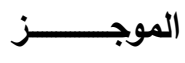

تم عزل 89 عزلة بكتيرية داخلية بطريقتين مختلفتين

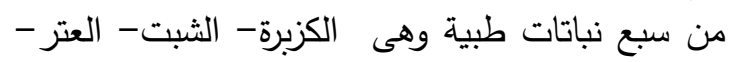

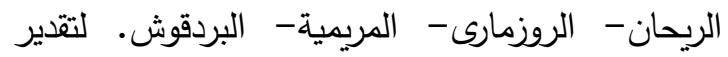
كفاءة النشاط البيولوجى لهذه العزلات كبكتريا داخلية تم التمان

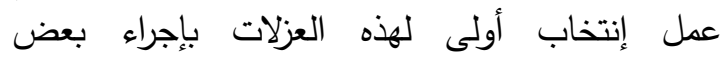

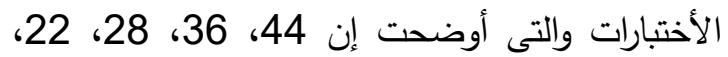
82 عزلة من المجموع الكلى للعزلات تعطى نتيجة موجبة لكلا من نشاط السليوليز والبكتينيز والأميليز وإنتاج الأندول أسيتك أسيد والجبريليك أسيد على على على التوالى. وتم إنتخاب أكفأ عشرون عزلة الإنيل بكتيرية ليتم عليهم الإنتخاب الثانى والذى يتضمن إنتان التبار القدرة التضادية لهذه العزلات ضد أربع فطريات مرضية التئية للنبات وإنتاجها للفضادات الأكسدة والمواد الفيعات الفينولية

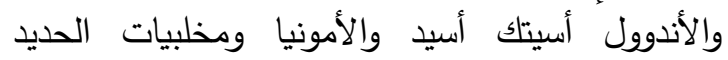
ونشاط إنزيم النيتروجينيز . تم إنتخاب أكفأ ستة عزلات الات

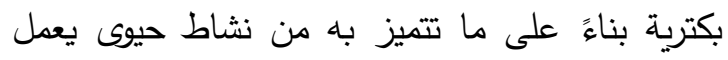
على زيادة نمو النبات، حيث سيث سجلت هنداة هذه العزلات

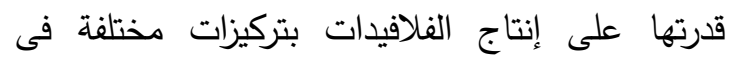
مزارعها وتراوحت تركيزاتها من 1.43 إلى 31.14 جزء فى المليون. كما لهم القدرة أيضا على إنتاج القلويدات فى مزارعهم ماعدا عزلة S14 ـ وقد سجلت 